\title{
PERANCANGAN PEMBUATAN DOKUMEN PENDATAAN BANGUNAN DALAM KOTA BUKITTINGGI
}

\author{
Rita Komalasari,S.Si.,M.Kom \\ Dosen Prodi Manajemen Informatika \\ Politeknik LP3I Bandung \\ Email: ritakomalasari123456@gmail.com
}

\begin{abstract}
Abstrak: Pendataan bangunan gedung adalah kegiatan penyimpanan data suatu bangunan gedung oleh Pemerintah Daerah yang dilakukan secara bersama dengan proses pembangunan gedung, proses SLF Bangunan Gedung dan pembongkaran Bangunan Gedung serta mendata dan mendaftarkan Bangunan. Gedung yang telah ada. Sasaran pendataan bangunan gedung yang dimaksud dalam perancangan ini adalah penyusunan seluruh bangunan gedung yang berada di wilayah kota Bukittinggi sehingga tercipta sistem informasi database yang akurat.
\end{abstract}

Kata Kunci: Pendataan Gedung, Database, Sistem informasi

\section{Pendahuluan}

\subsection{Latar Belakang Masalah}

Pembangunan nasional bertujuan untuk memajukan masyarakat secara umum sebagaimana dimuat di dalam Undang-Undang Dasar 1945 yang pada hakekatnya adalah pembangunan manusia Indonesia seutuhnya dan pembangunan seluruh masyarakat Indonesia. Disebutkan pula dalam risalah bahwa dimensi pembangunan tersebut menekankan pada keseimbangan pembangunan, kemakmuran lahiriah dan kepuasan batiniah, dalam suatu masyarakat Indonesia yang maju dan berkeadilan sosial berdasarkan Pancasila.

Dalam keterkaitan dengan peran dan fungsi bahwa bangunan gedung penting sebagai tempat manusia melakukan kegiatannya untuk mencapai berbagai sasaran yang menunjang terwujudnya tujuan pembangunan nasional. Oleh karena itulah berdasarkan latarbelakang tersebut, Pemerintah bertanggungjawab terhadap dasar penyelenggaraan bangunan gedung yang diwujudkan sesuai dengan fungsi fisiknya, serta dipenuhinya persyaratan administratif dan teknis bangunan gedung demi keamanan, keselamatan, kenyamanan dan produktifitas penghuninya. Dasar penyelenggaraan bangunan gedung ditetapkan Pemerintah dalam ketetapan Undang-Undang Republik Indonesia nomor 28 tahun 2002.

Berdasarkan hal tersebut maka Pemerintah Kota Bukittinggi melalui Dinas Pekerjaan Umum telah menyadari bahwa penyusunan data bangunan sangat penting dilakukan agar tercipta data base yang akurat. 
Kerangka Acuan Kerja (KAK) yang merupakan pedoman dasar untuk melaksanakan pekerjaan Pembuatan Dokumen Pendataan Bangunan Dalam Kota Bukittinggi, dapat dikatakan sudah cukup jelas sehingga tahapan pekerjaan dapat disusun dalam jadwal kegiatan secara rinci. Kerangka Acuan Kerja ini menjelaskan secara detail mengenai latar belakang, maksud dan tujuan, ruang lingkup pekerjaan, Tenaga Ahli dan Tenaga Pendukung serta kelengkapan Peralatan dan Dokumen yang diperlukan untuk melaksanakan pekerjaan dan keluaran yang harus diserahkan.

Tujuan kegiatan ini sudah cukup jelas, yaitu Pembuatan Dokumen Pendataan Bangunan dengan lokasi pada Kecamatan Guguk Panjang Kota Bukittinggi (7 Kelurahan ) dan Kecamatan Mandiangin Koto Selayan Kota Bukittinggi (9 Kelurahan).

Tujuan dilaksanakannya kegiatan ini yaitu

1. Pemantauan dan evaluasi bangunan sehingga terwujud tertib administrasi bangunan gedung.

2. Terlaksananya Pendataan Bangunan Gedung untuk mencapai tertib Administrasi Pembangunan dan Pemanfaatan Bangunan Gedung serta Sistim Informasi Bangunan Gedung.

Sasaran Pekerjaan :

1. Terkumpulnya data dan informasi rumah/bangunan gedung di Kota Bukittinggi di Kecamatan Guguk Panjang sebanyak 7 Kelurahan Kecamatan Mandiangin Koto Selayan sebanyak 9 Kelurahan terkait dengan aspek Fungsi dan administrasi, sesuai dengan ketentuan dalam Peraturan Menteri PekerjaanUmum No. 17/PRT/M tahun 2010 tentang Pedoman Teknis Pendataan Bangunan Gedung.

2. Diketahuinya informasi kesesuaian antara bangunan gedung dengan Rencana Tata Ruang Wilayah Kota Bukittinggi.

3. Diketahuinya kekayaan aset negara dan pendapatan daerah.

4. Teridentifikasinya permasalahan penyelenggaraan bangunan gedung di Kota Bukittinggi.

\section{Tinjauan Pustaka}

\subsection{Pengertian Pembuatan Dokumen Pendataan Bangunan Dalam Kota Bukittinggi}

Pada era teknologi informasi saat ini, penyajian data dituntut agar dapat lebih mempermudah dalam penggunaannya. Data digital merupakan solusi yang tepat dalam mengatasi permasalahan data yang belum terorganisasi.

Pendataan bangunan gedung adalah kegiatan pengumpulan data suatu bangunan gedung oleh pemerintah daerah yang dilakukan secara bersama dengan proses izin mendirikan bangunan gedung, proses sertifikat laik fungsi bangunan gedung, dan pembongkaran bangunan gedung, serta mendata dan mendaftarkan bangunan gedung yang telah ada. 
Bangunan gedung adalah wujud fisik hasil pekerjaan konstruksi yang menyatu dengan tempat kedudukannya, sebagian atau seluruhnya berada di atas dan atau di dalam tanah atau di air yang berfungsi sebagai tempat manusia melakukan kegiatannya, baik untuk hunian atau tempat tinggal, kegiatan keagamaan, kegiatan usaha, kegiatan sosial budaya maupun kegiatan khusus.

Berdasarkan hal tersebut maka Pemerintah Kota Bukittinggi melalui Dinas Pekerjaan Umum telah menyadari bahwa penyusunan data bangunan sangat penting dilakukan agar tercipta data base yang akurat. Geographic Information System (GIS) atau Sistem Informasi Geografis menjadi solusi dalam membuat pendataan bangunan khususnya di Kota Bukittinggi. GIS nantinya akan mampu memasukkan, menyimpan, mengulang, dan menyajikan data serta dapat memudahkan dalam pencarian informasi yang berkaitan dengan bangunan secara online.

\section{2..2 Ruang lingkup Pembuatan Dokumen Pendataan Bangunan Dalam Kota Bukittinggi}

Pekerjaan Pendataan Rumah dan Bangunan ini meliputi seluruh pekerjaan mulai dari persiapan hingga penyusunan buku laporan akhir yang menjadi landasan dalam pengambilan kebijakan dibidang tertib administrasi bangunan dan dalam pelaksanaan pembangunan kota. Secara umum ruang lingkup pekerjaan sesuai dengan Peraturan Menteri Pekerjaan Umum No. 17 PRT/M tahun 2010 tentang Pedoman Teknis Pendataan Bangunan Gedung.

Ruang lingkup dan batasan Pembuatan Dokumen Pendataan Bangunan Dalam Kota Bukittinggi adalah sebagai berikut:

1. Pembuatan database berdasarkan persyaratan pendataan bangunan gedung berupa data yang terbagi mejadi :

a. Data Umum (data kepemilikan, bangunan dan tanah),

1) Perorangan

a) Nama (sebagai perorangan atau wakil pemilik/pengguna);

b) Alamat (jalan, kelurahan/desa, dan kecamatan);

c) Nomor KTP atau bukti identitas diri lainnya;

2) Badan Usaha

a) Nama Perusahaan;

b) Alamat Perusahaan;

c) No. Akte Pendirian;

d) NPWP;

e) Telp/Fax;

f) E-mail;

3) Data Tanah
a) Nama pemilik tanah;
b) Nomor identitas pemilik tanah;
c) Nomor bukti kepemilikan tanah; 
d) Jenis kepemilikan tanah;

e) Alamat tanah (jalan, kelurahan/desa, dan kecamatan);

f) Luas tanah

g) Data peruntukan

h) Data intensitas pembangunan untuk lokasi terkait (KDB, KLB, KDH, dan KTB)

4) Data Bangunan Gedung
a) Nama bangunan;
b) Alamat bangunan;
c) Fungsi bangunan;
d) Klasifikasi bangunan;
e) Jumlah lantai bangunan;
f) Luas lantai bangunan;
g) Ketinggian bangunan;
h) Luas basement;
i) Jumlah lantai basement;
j) Posisi bangunan gedung berdasarkan informasi GPS (sebaiknya diambil di titik tengah bangunan gedung);
k) Tanggal mulai dan selesai konstruksi untuk bangunan baru

b. Data Status (data riwayat bangunan gedung)

1) Data status pemilik bangunan terdahulu
a) Perorangan
b) Badan Usaha
c) Negara
d) Data status administrasi bangunan

c. Data Teknis (data teknis bangunan, arsitektur, struktur dan utilitas)

1) Data teknis struktur
a) Jenis struktur pondasi;
b) Jenis struktur utama;
c) Jenis struktur atap;

2) Data teknis arsitektur
a) Data intensitas bangunan (KDB, KLB, KDH, dan sebagainya);
b) Dokumen perencanaan arsitektur;
c) Luas ruang terbuka hijau dan dokumen perencanaan ruang terbuka hijau;
d) Dokumen perencanaan pencahayaan;
e) Data akesesibilitas berupa dokumen perencanaan aksesibilitas;

3) Data teknis utilitas
a) Data kelistrikan
b) Data sistem proteksi kebakaran
c) Data alat bantu transportasi yang digunakan dalam bangunan
d) Data instalasi komunikasi
e) Data penghawaan buatan
f) Data instalasi air bersih
g) Data instalasi air kotor dan pengelolaan limbah 
4) Data penyedia jasa

a) Penyedia jasa perencanaan (struktur, arsitektur, dan utilitas)

b) Penyedia jasa pelaksanaan (struktur, arsitektur, dan utilitas)

c) Penyedia jasa pengawasan (struktur, arsitektur, dan utilitas)

2. Data terkait proses administrasi

a. Data terkait proses IMB

1) Data terkait kelengkapan administrasi pemohon IMB. Data kelengkapan administrasi ini sesuai dengan proses IMB, antara lain :
a) Surat permohonan IMB
b) Lampiran IMB terdahulu untuk proses re-IMB
c) Fotocopy identitas pemohon
d) Surat pajak
e) SIPPT
f) Surat kuasa pengurusan IMB / re-IMB
g) Surat rekomendasi dari desa/kelurahan
h) Surat rekomendasi dari kecamatan
i) Surat perjanjian sewa tanah bila pemilik bangunan berbeda dengan pemilik tanah
j) Dokumen teknis perencanaan
k) Surat Keterangan Rencana Kota
1) Surat bukti pembayaran retribusi
m)Berita acara pemeriksaan setelah dokumen teknis dikaji oleh Pemda

2) Data terkait kemajuan permohonan IMB antara lain:
a) Dokumen permohonan IMB telah diterima
b) Dokumen permohonan IMB telah diperiksa
c) Inspeksi lapangan
d) IMB telah diterbitkan/ditolak serta alasannya jika ditolak

b. Data terkait proses SLF/SLFn

1) Data terkait kelengkapan administrasi pemohon SLF. Data kelengkapan administrasi ini sesuai dengan prosesSLF (Permen no. 25/2007), antara lain:
a) Surat permohonan SLF
b) IMB untuk SLF
c) IMB dan SLF sebelumnya jika SLFn
d) Fotocopy identitas pemohon
e) Surat kuasa pengurusan SLF
f) Dokumen teknis
g) Surat bukti pembayaran retribusi
h) Berita acara pemeriksaan setelah bangunan dikaji oleh penilai kelayakan

2) Data terkait kemajuan proses permohonan SLF
a) Dokumen permohonan SLF telah diterima
b) Dokumen permohonan SLF telah diperiksa
c) Inspeksi lapangan
d) SLF telah diterbitkan/ditolak serta alasannya jika ditolak

c. Data terkait proses pembongkaran/pelestarian 
1) Data terkait kelengkapan administrasi pemohon pembongkaran.

a) Surat permohonan/ajuan pembongkaran/ pelestarian

b) Fotocopy identitas pemohon

c) Surat kuasa permohonan pembongkaran/ pelestarian

d) Dokumen teknis usulan pembongkaran

e) Berita acara pemeriksaan dokumen usulan pembongkaran atau kajian pelestarian.

2) Data terkait kemajuan proses permohonan pembongkaran/pelestarian
a) Dokumen permohonan pembongkaran/pelestarian telah diterima
b) Dokumen permohonan pembongkaran/pelestarian telah diperiksa
c) Inspeksi lapangan
d) Perintah pembongkaran telah diterbitkan / ditolak serta alasannya jika ditolak

3. Formulir Data (input), Pertanyaan (queries), Laporan (report)

a. Formulir pendataan bangunan (input) yang akan digunakan untuk memasukkan data yang belum ada sebelumnya dan updating data yang telah ada. Pengambilan data sesuai formulir meliputi :

1) Status kepemilikan Tanah dimana bangunan berdiri dan riwayat kepemilikan dan/atau penguasaan apabila diperlukan

2) Izin Mendirikan Bangunan

3) Lokasi Bangunan

4) Jenis Konstruksi Bangunan

5) Luas Bangunan \& Gambar Denah Bangunan

6) Pengguna Bangunan

7) Fungsi Bangunan

8) Klasifikasi Bangunan

9) Sumber air bersih yang digunakan

10) Sumber penerangan yang digunakan

11) Septick tank

12) lain-lain

b. Pertanyaan (queries) yang akan digunakan untuk pengambilan informasi dari data yang telah tersimpan dalam data base.

c. Format Laporan (output) yang akan digunakan pada saat diperlukan pembuatan laporan dari hasil

4. Fungsi dan Klasifikasi

a. Fungsi bangunan gedung meliputi :

1) Fungsi hunian, merupakan bangunan dengan fungsi utama sebagai tempat tinggal manusia yang meliputi :

a) Rumah tinggal tunggal

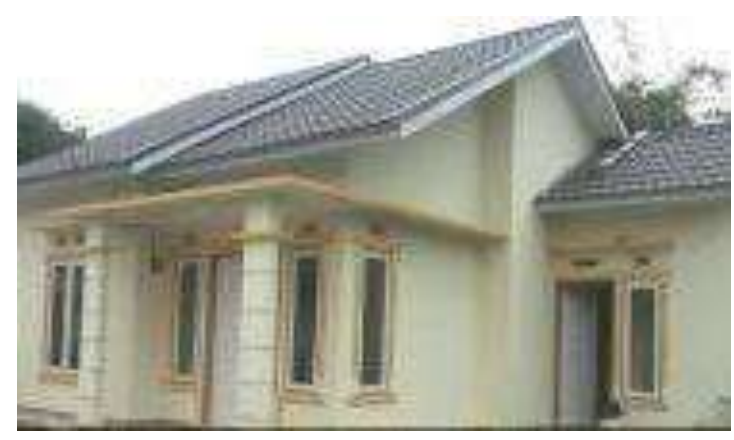




\section{Gambar 2.1 Rumah Tinggal Tunggal}

b) Rumah tinggal deret

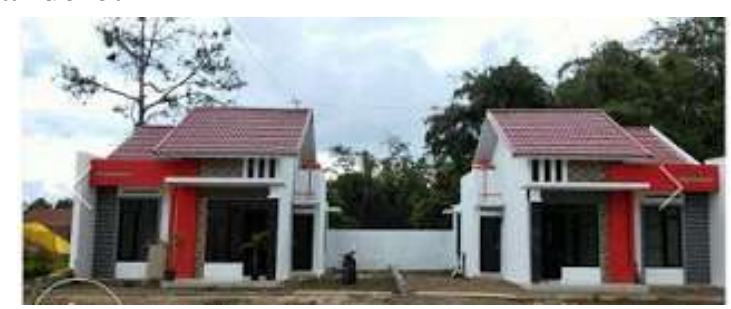

Gambar 2.2 Rumah Deret

c) Rumah tinggal susun

d) Rumah tinggal sementara

2) Fungsi keagamaan, merupakan bangunan dengan fungsi utama sebagai tempat melakukan ibadah yang meliputi bangunan masjid termasuk musholla, bangunan gereja termasuk kapel, bangunan pura, bangunan vihara, dan bangunan kelenteng.

3) Fungsi usaha, merupakan bangunan dengan fungsi utama sebagai tempat melakukan kegiatan usaha yang meliputi:

a) Bangunan perkantoran : perkantoran pemerintah, perkantoran niaga, dan sejenisnya
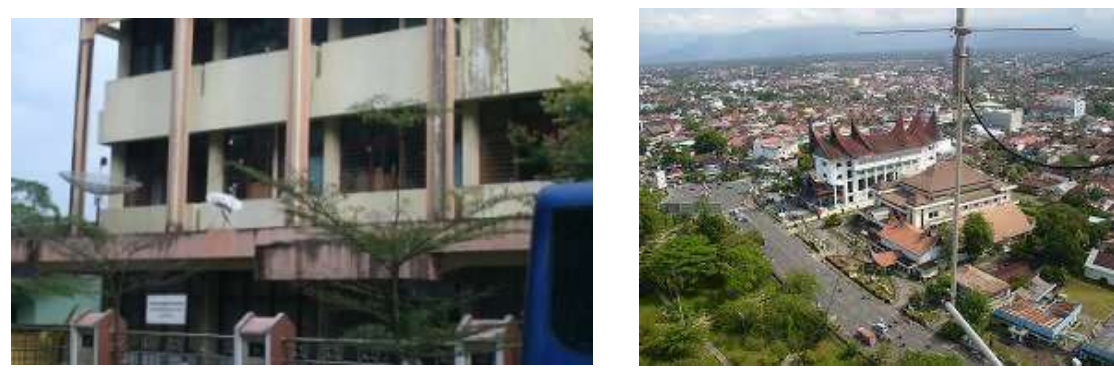

Gambar 2.3 Kantor pemerintahan

b) Bangunan perdagangan : pasar, pertokoan, pusat pembelanjaan, mal, dan sejenisnya.

c) Bangunan perindustrian : industri kecil, industri sedang, industri besar/berat.

d) Bangunan perhotelan/penginapan: hotel, motel, hostel, penginapan, dan sejenisnya.

e) Bangunan wisata dan rekreasi : tempat rekreasi, bioskop, dan sejenisnya

f) Bangunan terminal : stasiun kereta, terminal bus, terminal udara, halte bus, pelabuhan laut.

g) Bangunan tempat penyimpanan : gudang, gedung parkir dan sejenisnya.

4) fungsi sosial dan budaya, Merupakan bangunan dengan fungsi utama sebagai tempat melakukan kegiatan sosial dan budaya meliputi bangunan gedung dengan fungsi utama untuk :

a) Bangunan pendidikan: sekolah taman kanak-kanak, sekolah dasar, sekolah lanjutan, perguruan tinggi/universitas.

[1] Bangunan pelayanan kesehatan : puskesmas, poliklinik, rumah bersalin, rumah sakit kelas A, B, dan C, dan sejenisnya.

[2] Bangunan kebudayaan : museum, gedung kesenian dan sejenisnya. 
5) Fungsi khusus meliputi bangunan gedung dengan fungsi utama yang mempunyai tingkat kerahasiaan tinggi tingkat nasional atau yang penyelenggaraannya dapat membahayakan masyarakat sekitarnya dan/atau mempunyai risiko bahaya tinggi yang meliputi bangunan gedung untuk reaktor nuklir, instalasi pertahanan dan keamanan, dan bangunan sejenis yang ditetapkan oleh Menteri.

6) Fungsi Campuran, Dalam suatu persil, kaveling, atau blok peruntukan dimungkinkan adanya fungsi campuran (mixed use), sepanjang sesuai dengan peruntukan lokasinya dan/atau Rencana Tata Bangunan dan Lingkungan.

b. Klasifikasi bangunan Bangunan gedung dibagi berdasarkan klasifikasinya menjadi:

1) Klasifikasi gedung berdasarkan kompleksitas :

a) Bangunan gedung sederhana adalah bangunan dengan karakter sederhana serta memilki kompleksitas dan teknologi sederhana.

b) Bangunan gedung tidak sederhana adalah bangunan gedung dengan karakter tidak sederhana serta memilki kompleksitas dan teknologi tidak sederhana.

c) Bangunan gedung khusus adalah bangunan yang memiliki penggunaan dan persyaratan khusus, yang dalam perencanaan dan pelaksanaannya memerlukan penyelesaian/ teknologi khusus.

2) Klasifikasi berdasarkan tingkat permanensi :

a) Bangunan gedung darurat atau sementara adalah bangunan gedung yang karena fungsinya direncanakan mempunyai umur layanan sampai dengan 5 (lima) tahun.

b) Bangunan gedung semi permanen adalah bangunan gedung yang karena fungsinya direncanakan mempunyai umur layanan diantara 5 (lima) s/d 10 (sepuluh) tahun.

c) Bangunan gedung permanen adalah bangunan gedung yang karena fungsinya direncanakan mempunyai umur layanan diatas 20 tahun.

3) Klasifikasi berdasarkan tingkat resiko kebakaran:

a) Tingkat risiko kebakaran rendah adalah bangunan gedung yang karena fungsinya, dan didesain penggunaan bahan dan komponen unsur pembentuknya, serta kuantitas dan kualitasnya bahan yang ada di dalamnya tingkat mudah terbakarnya sangat rendah.

b) Tingkat risiko kebakaran sedang adalah bangunan gedung yang karena fungsinya, dan didesain penggunaan bahan dan komponen unsur pembentuknya, serta kuantitas dan kualitasnya bahan yang ada di dalamnya tingkat mudah terbakarnya sedang.

c) Tingkat risiko kebakaran tinggi adalah bangunan gedung yang karena fungsinya, dan didesain penggunaan bahan dan komponen unsur pembentuknya, serta kuantitas dan kualitasnya bahan yang ada di dalamnya tingkat mudah terbakarnya sangat tinggi.

4) Klasifikasi berdasarkan Zonasi Gempa, zonasi gempa yang ada di Indonesia berdasarkan tingkat kerawanan bahaya gempa sesuai peraturan/standar teknis yang terkait dengan zonasi atau mikro zonasi gempa setempat yang berlaku.

5) Klasifikasi berdasarkan tingkat kepadatan lokasi :

a) Bangunan gedung di lokasi renggang. 
b) Bangunan gedung di lokasi sedang.

c) Bangunan gedung di lokasi padat.

6) Klasifikasi berdasarkan ketingggian :

a) Bangunan rendah yaitu bangunan gedung dengan jumlah lantai bangunan gedung sampai dengan 4 lantai,

b) Bangunan sedang yaitu bangunan gedung dengan jumlah lantai bangunan gedung 5 lantai sampai dengan 8 lantai,

c) Bangunan tinggi yaitu bangunan gedung dengan jumlah lantai bangunan lebih dari 8 lantai.

7) Klasifikasi berdasarkan kepemilikan :

a) Bangunan gedung milik negara, yayasan.

b) Bangunan gedung milik perorangan.

c) Bangunan gedung milik badan usaha.

8) Klasifikasi berdasarkan tingkat kesejarahannya, Bangunan gedung dan lingkungannya sebagai benda cagar budaya dan/atau bersejarah yang dilindungi dan dilestarikan merupakan bangunan gedung berumur paling sedikit 50 (lima puluh) tahun, atau mewakili masa gaya sekurang-kurangnya 50 (lima puluh) tahun, serta dianggap mempunyai nilai penting sejarah, ilmu pengetahuan, dan kebudayaan termasuk nilai arsitektur dan teknologinya yang ditetapkan oleh bupati/walikota sesuai dengan peraturan.

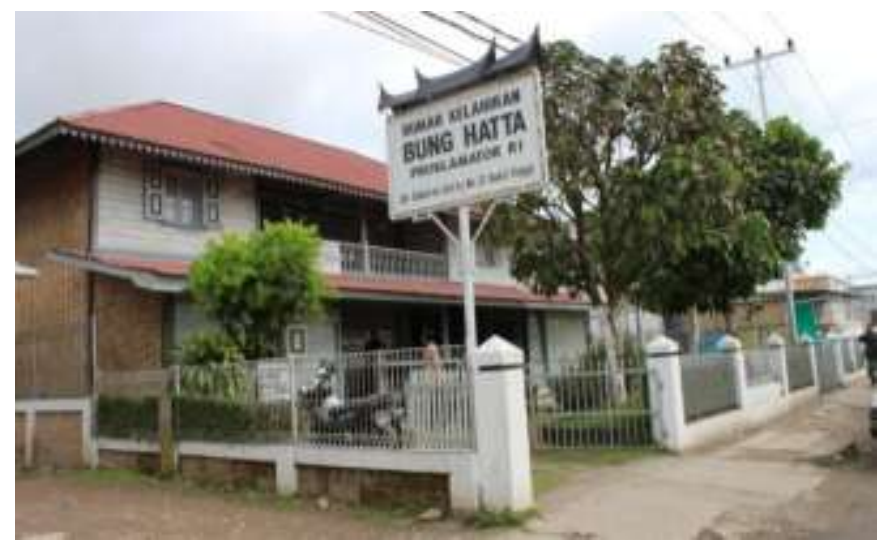

Gambar 2.4 Bangunan bersejarah

Bangunan gedung yang didirikan harus memenuhi persyaratan kepadatan dan ketinggian bangunan gedung berdasarkan rencana tata ruang wilayah Daerah yang bersangkutan, rencana tata bangunan dan lingkungan yang ditetapkan, dan peraturan bangunan setempat.

Ketentuan-ketentuan tata bangunan dan lingkungan pada suatu lingkungan/ kawasan menjelaskan mengenai Intensitas Pemanfaatan Lahan yang merupakan tingkat alokasi dan distribusi luas lantai maksimum bangunan terhadap lahan/tapak peruntukannya.

Kepadatan bangunan meliputi ketentuan tentang Koefisien Dasar Bangunan (KDB), yaitu angka persentase perbandingan antara luas seluruh lantai dasar bangunan gedung yang dapat dibangun dan luas lahan/ tanah perpetakan/daerah perencanaan yang dikuasai. yang dibedakan dalam tingkatan KDB padat, sedang, dan renggang. 
Ketinggian bangunan meliputi ketentuan tentang Jumlah Lantai Bangunan (JLB), dan Koefisien Lantai Bangunan (KLB) yaitu angka desimal perbandingan antara jumlah seluruh luas lantai seluruh bangunan yang dapat dibangun dan luas lahan/ tanah perpetakan/daerah perencanaan yang dikuasai, yang dibedakan dalam tingkatan KLB tinggi, sedang, dan rendah. Daerah Manfaat Jalan (DAMAJA) merupakan ruang sepanjang jalan yang dibatasi oleh lebar, tinggi, dan kedalaman ruang bebas tertentu yang ditetapkan oleh pembina jalan.

Daerah Milik Jalan (DAMIJA) merupakan ruang sepanjang jalan yang dibatasi oleh lebar, tinggi tertentu yang dikuasai oleh pembina jalan dengan suatu hak tertentu sesuai dengan peraturan perundang-undangan yang berlaku.

Daerah Pengawasan Jalan (DAWASJA) merupakan ruang sepanjang jalan di luar daerah milik jalan yang dibatasi oleh lebar dan tinggi tertentu, yang ditetapkan oleh pembina jalan, dan diperuntukkan bagi pandangan bebas pengemudi dan pengamanan konstruksi jalan.

Field yang akan ada dalam perancangan database adalah sebagai berikut :

- ID_Persil

- Nama_Pemilik

- Lokasi

- RT

- RW

- Kelurahan

- Kecamatan

- Kota/ Kabupaten

- Propinsi

- Fungsi

- Luas

Kondisi Fisik (Struktur) :

- Pondasi (jenis)

- Tiang (kolom)

- Struktur (Bahan)

- Tinggi Bangunan

- Jumlah Lantai

- Dokumen IMB

- Dokumen Pendukung lainnya

- Posisi Koordinat Lokasi bangunan

- dll

\subsection{Kajian Kebijakan Pembuatan Dokumen Pendataan Bangunan Dalam Kota Bukittinggi}

Dalam rangka implementasi Pembuatan Dokumen Pendataan Bangunan Dalam Kota Bukittinggi telah disusun sejumlah peraturan yang berperan dalam kegiatan Pembuatan Dokumen Pendataan Bangunan Dalam Kota Bukittinggi. Kebijakan tersebut merupakan rencana dan kebijakan yang diambil oleh pemerintah untuk mewujudkan Pembuatan Dokumen Pendataan Bangunan Dalam Kota Bukittinggi yang optimal. 
Peraturan perundang-undangan yang terkait dengan Pembuatan Dokumen Pendataan Bangunan Dalam Kota Bukittinggi adalah sebagai berikut:

1. Undang-undang Nomor 4 Tahun 1992 tentang Perumahan dan Pemukiman.

2. Undang-undang No.23 Tahun 1997 tenetang Pengelolaan Lingkungan Hidup.

3. Undang-undang No. 28 Tahun 2002 tentang Bangunan Gedung.

4. Undang-undang No.26 Tahun 2007 tentang Penataan Ruang.

5. Undang-undang No.32 Tahun 2009 tentang Perlindungan dan Pengelolaan Lingkungan Hidup.

6. Undang-undang No.4 Tahun 2011 tentang Informasi Geopasial.

7. Peraturan Pemerintah No. 15 Tahun 2010 tentang Penyelenggaraan Penataan Ruang

8. Peraturan Menteri Pekerjaan Umum Nomor 06/PRT/M/2007 tentang Rencana Pedoman Umum Penyusunan RTBL.

9. Peraturan Menteri Pekerjaan Umum Nomor 17/PRT/M/2010 tentang Pedoman Teknis Pendataan Bangunan Gedung.

10. Peraturan Daerah Kota Bukittinggi No. 06 Tahun 2011 tentang Rencana Tata Ruang Wilayah (RTRW) Kota Bukittinggi Tahun 2010-2030

11. Peraturan Daerah Kota Bukittinggi No. 1 Tahun 2015 tentang Bangunan Gedung Kota Bukittinggi

12. Peraturan Daerah Kota Bukittinggi Nomor 13 Tahun 2016 tentang Anggaran Pendapatan dan Belanja Daerah Tahun Anggaran 2017;

13. Peraturan Walikota Bukittinggi Nomor 69 Tahun 2016 tentang Penjabaran Anggaran Pendapatan Belanja Daerah Tahun Anggaran 2017;

\subsection{Metode Pengembangan GIS}

SIG adalah sistem yang berbasiskan komputer yang digunakan untuk menyimpan dan memanipulasi informasi-informasi geografis. SIG dirancang untuk mengumpulkan, menyimpan, dan menganalisis objekobjek dan fenomena di mana lokasi geografis merupakan karakteristik yang penting atau kritis untuk dianalisis. Dengan demikian, SIG merupakan sistem komputer yang memiliki empat kemampuan berikut dalam menangani data yang bereferensi geografis: (a) masukan, (b) manajemen data (penyimpanan dan pemanggilan data), (c) analisis dan manipulasi data, dan (d) keluaran.

Data geografis pada dasarnya tersusun oleh dua komponen penting yaitu data spasial dan data atribut. Perbedaan antara dua jenis data tersebut adalah sebagai berikut : 1. Data Spasial Data spasial adalah data yang bereferensi geografis atas representasi objek di bumi. Data spasial pada umumnya berdasarkan peta yang berisikan interpretasi dan proyeksi seluruh fenomena yang berada di bumi. Sesuai dengan perkembangan, peta tidak hanya merepresentasikan objek-objek yang ada di muka bumi, tetapi berkembang menjadi representasi objek di atas muka bumi (di udara) dan di bawah permukaan bumi. Data spasial dapat diperoleh dari berbagai sumber dalam berbagai format. Sumber data spasial antara lain mencakup: data grafis peta analog, foto udara, citra satelit, survei lapangan, pengukuran theodolit, pengukuran dengan menggunakan global positioning systems (GPS) dan lain-lain. 


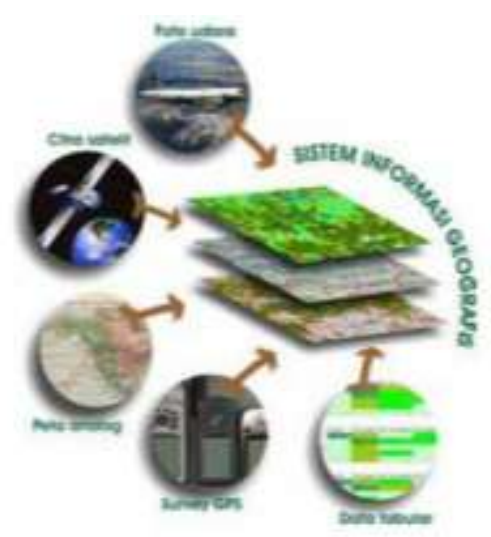

Gambar 2.5 Sumber Data dalam SIG

Wilayah Kota Bukittinggi terletak pada ketinggian antara 780 - 950 mdpl. Topografi wilayah umumnya relatif datar, tetapi terdapat perbukitan yang bergelombang dan berbukit. Namun permukaan wilayah yang bergelombang dan berbukit diarea pinggir berakibat terhadap terbatasnya wilayah yang dapat dimanfaatkan untuk pemukiman dan kegiatan pembangunan perkotaan. Konsekuensinya penduduk tidak tersebar merata dalam wilayah kota. Pada wilayah tertentu penduduknya sangat padat dan sebaliknya terdapat wilayah dengan densitas penduduk rendah.

\subsubsection{ArcGIS}

ArcGIS merupakan kompilasi beberapa fungsi dari berbagai macam perangkat GIS seperti GIS desktop, server, dan GIS berbasis web. Perangkat lunak ini dirilis ESRI Pada tahun 2000. Produk Utama Dari ArcGIS adalah ArcGIS desktop, yang mana ArcGIS desktop merupakan perangkat GIS professional komprehensif dan dikelompokkan atas tiga komponen yaitu: ArcView, ArcEditor dan ArcInfo. Software ArcGIS pertama kali diperkenalkan kepada publik oleh ESRI pada tahun 1999, yaitu dengan kode versi 8.0 (ArcGIS 8.0). ArcGIS merupakan penggabungan, modifikasi dan peningkatan dari 2 perangkat lunak ESRI yang sudah terkenal sebelumnya yaitu ArcView GIS 3.3 (ArcView 3.3) dan ArcInfo Workstation 7.2 (terutama untuk tampilannya).

Perangkat lunak berbasis Windows ArcGIS meliputi sebagai berikut :

1. ArcReader, pengguna memungkinkan menampilkan peta yang dibuat menggunakan produk ArcGIS lain.

2. ArcGIS Desktop, mempunyai lima tingkat lisensi :

a. ArcView, pengguna memungkinkan menampilkan data spasial, pembuatan peta berlapis, dan melakukan analisa spasial dasar.

b. ArcMap, merupakan aplikasi utama dalam proses GIS dan pemetaan menggunakan komputer. ArcMap mempunyai kemampuan utama guna visualisasi, pembangunan database spasial baru, editing, memilih (query), menciptakan desain peta, analisa dan pembuatan tampilan akhir pada laporan kegiatan. Hal-hal yang dapat dilakukan ArcMap 
antara lain yaitu penjelajahan data (exploring), presenting result, analyzing, customizing data dan programming.

c. ArcEditor, mempunyai kemampuan sama dengan ArcView ditambah peralatan manipulasi berkas shapefile dan geodatabase.

d. ArcInfo, memiliki kemampuan seperti ArcEditor dengan tambahan fungsi manipulasi data, analisis, dan penyuntingan.

e. ArcCatalog, alat yang berguna untuk menjelajah (browsing), mengatur (organizing), mendokumentasikan data spasial atau metadata, membagi (distribution), dan menyimpan (documentation) berbagai data SIG. ArcCatalog dapat membantu proses eksplorasi dan pengelolaan data spasial. Ketika data telah terhubung, ArcCatalog dapat digunakan untuk melihat data. Jika ada data yang akan digunakan, penambahan pada peta dapat ditambahkan secara langsung. Seringkali, ketika memperoleh data dari pihak lain, data tidak dapat langsung digunakan. Data tersebut memungkinkan masih memerlukan pengubahan sistem koordinat atau proyeksinya, pemodifikasian atribut, atau penghubungan antara data geografis 30 dengan atribut yang tersimpan dalam tabel terpisah. Ketika data telah siap, isi dan struktur data sebagaimana perubahanperubahan yang telah diolah, harus melakukan pendokumentasian. Aktifitas-aktifitas pengelolaan data dapat dilakukan menggunakan fasilitas yang ada dalam ArcCatalog

\subsubsection{Google Maps}

Google Maps adalah layanan pemetaan web yang dikembangkan oleh Google. Layanan ini memberikan citra satelit, peta jalan, panorama $360^{\circ}$, kondisi lalu lintas. Google Maps menawarkan API (Application Programming Interface) yang memungkinkan peta untuk dimasukkan pada situs web pihak ketiga, dan menawarkan penunjuk lokasi untuk bisnis perkotaan dan organisasi lainnya di berbagai negara di seluruh dunia. Tampilan satelit Google Maps adalah "top-down". Sebagian besar citra resolusi tinggi dari kota adalah foto udara yang diambil dari pesawat pada ketinggian 800 sampai 1.500 kaki (240-460 meter), sementara sebagian besar citra lainnya adalah dari satelit.
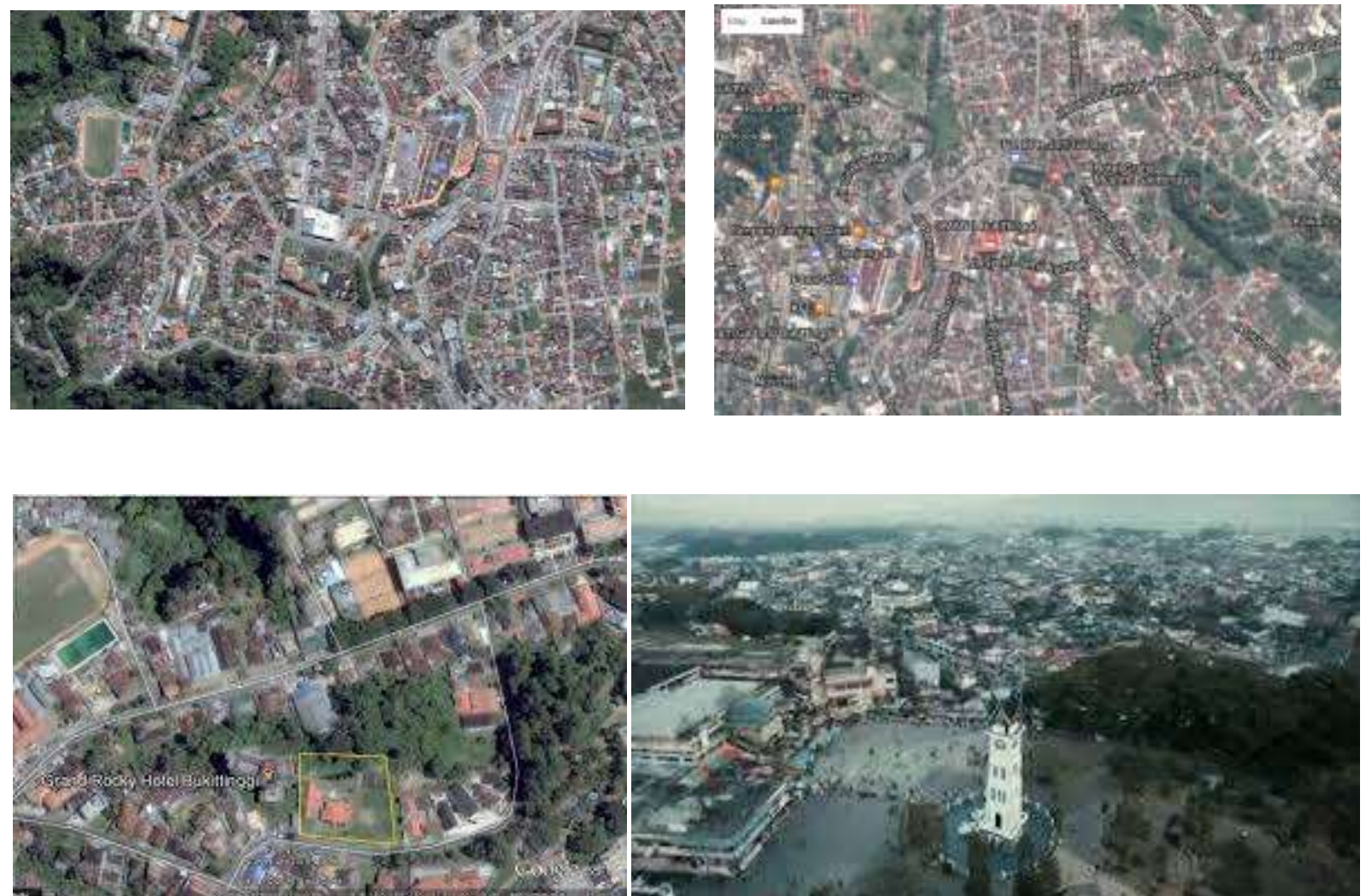



Gambar 2.6 Tampilan wilayah Bukittinggi melalui Google Maps

\subsubsection{MySQL}

MySQL adalah sebuah program database server yang mampu menerima dan mengirimkan datanya dengan sangat cepat, multi user, serta menggunakan perintah standar SQL. MySQL merupakan Free Software dibawah lisensi GNU/GPL (General Public License).

\subsection{Metodologi Pekerjaan}

\subsubsection{Metodologi Survey}

Survei penentuan posisi dari suatu jaringan titik di permukaan bumi umumnya dilakukan dengan metode pengukuran secara terestris yaitu dengan menentukan sudut/arah terhadap utara, jarak dan beda tingginya. Survei yang berbasis pada pengamatan ke satelit GPS dilakukan dengan metode reseksi (pengikatan ke belakang) yaitu titik-titik target di permukaan bumi ditentukan dari penghitungan jarak ke beberapa satelit (GPS) sekaligus. Metode seperti ini disebut dengan metode penentuan posisi secara absolut (absolut positioning/point positioning) yang merupakan metode penentuan posisi yang paling mendasar dari GPS. Kegiatan ini bertujuan untuk mendapatkan koordinat dan gambar bangunan serta melakukan pemetaan topografi menggunakan metode survei GPS dan memanfaatkan kemajuan perangkat lunak (software) untuk mengolah data posisi hasil pengukuran dengan GPS. Daerah yang akan dilakukan kegiatan survey untuk pendataan bangunan gedung adalah Kecamatan Guguk Panjang (7 Kelurahan) dan Kecamatan Mandiangin Koto Selayan (9 Kelurahan). 


\section{Peralatan Survey}

Sebelum pelaksanaan pekerjaan dimulai harus ditentukan terlebih dahulu peralatan yang akan digunakan. Peralatan yang digunakan harus memenuhi spesifikasi teknis yang ada sehingga data pengukuran memenuhi kriteria yang diinginkan (telah dikalibrasi).

Peralatan yang harus dipersiapkan antara lain :

1. Leica DISTO D810 Touch adalah alat ukur jarak laser yang dilengkapi dengan 15 mode pengukuran dengan tingkat akurasi hingga 1/16 inci. Alat ukur jarak ini dilengkapi dengan fitur User Interface layar sentuh, kamera digital terintegrasi, sensor kemiringan, dan Bluetooth.

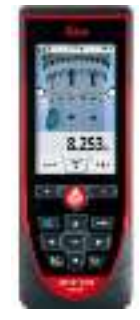

Gambar 2.7 Alat ukur jarak

2. Komputer (hardware dan software) + printer ukuran A3

3. Kamera

4. Kompas

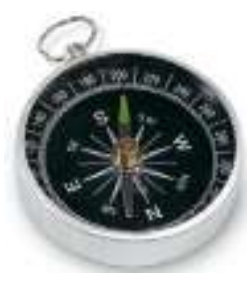

Gambar 2.8 Kompas

5. GPS Handheld (New Genuine Can-am 20162017 Outlander Max 850 Garmin Montana 680t Gps \& Mount)

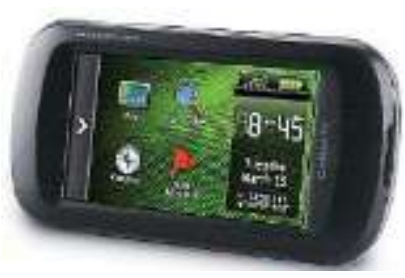

Gambar 2.9 GPS (Global Positioning System)

6. Perlengkapan lapangan

\section{Kegiatan survey}

Kota Bukittinggi merupakan salah satu wilayah administratif di Provinsi Sumatera Barat yang terletak diantara 100020' - 100025' BT dan 00016' -00020' LS. Luas wilayah Kota Bukittinggi mencapai 25,24 km2, atau 0,06\% dari luas total wilayah Provinsi Sumatera Barat. 

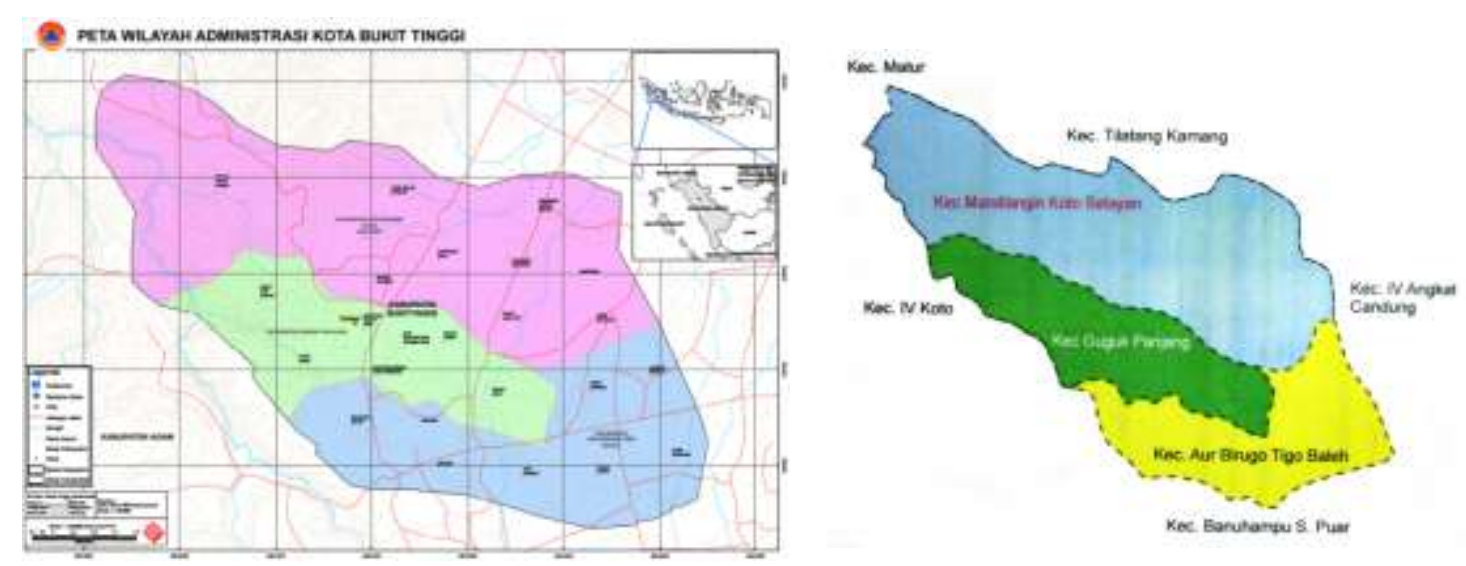

Gambar 2.10 Peta Administrasi Kota Bukittinggi

Surveyor (6 orang) melakukan survey ke bangunan gedung yang didata untuk mendapatkan data di Kecamatan Guguk Panjang sebanyak 7 Kelurahan dan Kecamatan Mandiangin Koto Selayan sebanyak 9 Kelurahan dengan melibatkan tim/aparat Kelurahan/RW/RT setempat.

1. Kecamatan Guguk Panjang Kota Bukittinggi dengan luas areal 6,831 km2 (683,10 ha) atau $27,06 \%$ dari total luas Kota Bukittinggi yang meliputi 7 kelurahan. Lingkup Kelurahan meliputi :

a. Kelurahan Bukit Cangang Kayu Ramang

b. Kelurahan Tarok Dipo

c. Kelurahan Pakan Kurai

d. Kelurahan Aur Tajungkang Tangah Sawah

e. Kelurahan Benteng Pasar Atas

f. Kelurahan Kayu Kubu

g. Kelurahan Bukit Apit Puhun

2. Kecamatan Mandiangin Koto Selayan Kota Bukittinggi, dengan luas areal 12,156 km2 $(1.215,60 \mathrm{ha})$ atau $48 \%$ dari total luas Kota Bukittinggi yang meliputi 9 kelurahan. Lingkup Kelurahan meliputi :

a. Kelurahan Campago Ipuh

b. Kelurahan Puhun Pintu Kabun

c. Kelurahan Puhun Tembok

d. Kelurahan Pulai Anak Air

e. Kelurahan Manggis Ganting

f. Kelurahan Garegeh

g. Kelurahan Campago Guguk Bulek

h. Kelurahan Koto Selayan

i. Kelurahan Kubu Gulai Bancah

\section{Perkiraan jumlah waktu pengerjaan survey}

Survey dilakukan ke 16 kelurahan di 2 kecamatan untuk mengetahui data bangunan. 
Tabel 2.1 Asumsi Jumlah Kepala Keluarga per Kecamatan

\begin{tabular}{|l|l|l|l|l|l|l|l|}
\hline NO & KECAMATAN & $\begin{array}{l}\text { JML PEN } \\
\text { DUDUK }\end{array}$ & $\begin{array}{l}\text { JML } \\
\text { KELU } \\
\text { RAHAN }\end{array}$ & $\begin{array}{l}\text { KK/ KELU } \\
\text { RAHAN }\end{array}$ & $\begin{array}{l}\text { KK } \\
/ \text { RW } *\end{array}$ & $\begin{array}{l}\text { KK } \\
/ \text { RT } * *\end{array}$ & $\begin{array}{l}\text { KK/ } \\
\text { KECA } \\
\text { MATAN }\end{array}$ \\
\hline 1 & Guguk Panjang & 42627 & 7 & 1522 & 114 & 38 & 10657 \\
\hline 2 & $\begin{array}{l}\text { Mandiangin } \\
\text { Koto Selayan }\end{array}$ & 46342 & 9 & 1287 & 97 & 32 & 11586 \\
\hline \multicolumn{7}{|l|}{ JUMLAH }
\end{tabular}

Ket : * setiap $1 \mathrm{RW}$ terdapat $3 \mathrm{RT}$

** setiap $1 \mathrm{RT}$ terdapat $40 \mathrm{KK}$

Tabel 2.2 Asumsi Data Kepala Keluargaper Hari Kerja per 1 Surveyor

\begin{tabular}{|l|l|l|l|l|}
\hline \multirow{2}{*}{$\begin{array}{l}\text { JML } \\
\text { SURVEYOR }\end{array}$} & JML & $\begin{array}{l}\text { JML DATA KK } \\
\text { BULAN } \\
\text { KERJA }\end{array}$ & $\begin{array}{l}\text { SELAMA BULAN } \\
\text { KERJA }\end{array}$ & $\begin{array}{l}\text { KK/HARI } \\
\text { KERJA* }\end{array}$ \\
\hline 6 & 3707 & 4,5 & 824 & 37 \\
\hline
\end{tabular}

Ket : * Hari kerja adalah 22 hari

\subsubsection{Metodologi Data Hasil Survey}

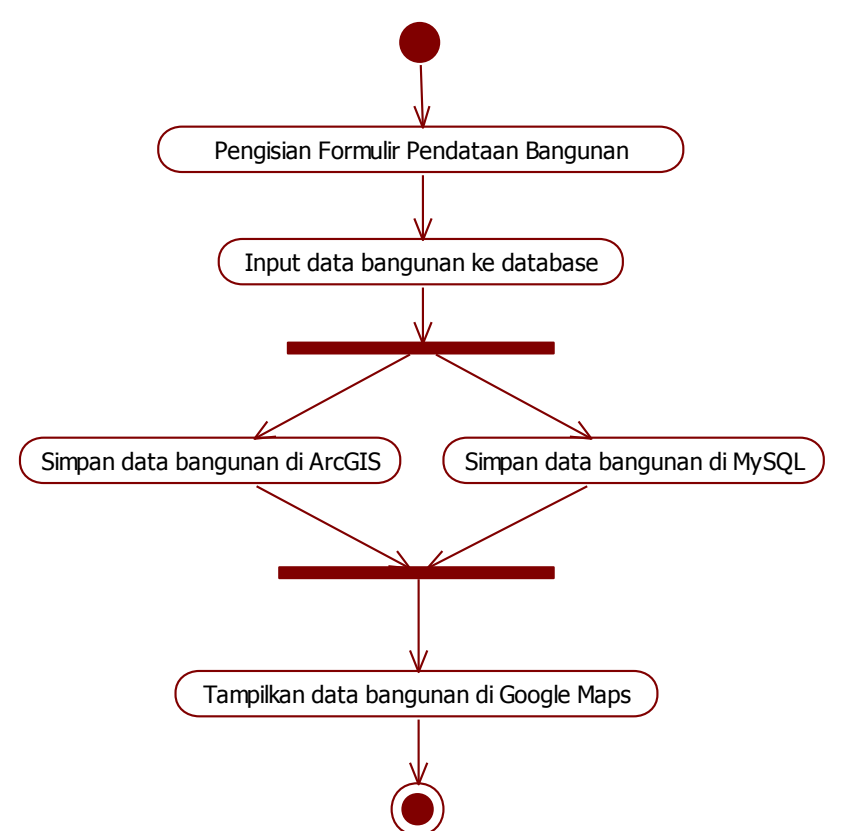

Gambar 2.11 Metodologi Data Hasil Survey

Deskripsi gambar adalah sebagai berikut :

1. Data hasil survey diisikan ke dalam formulir pendataan gedung.

2. Data bangunan diinputkan ke dalam database

3. Data bangunan disimpan dalam ArcGIS / MySQL (dimana selanjutnya apabila diinginkan data yang ada dalam ArcGIS dapat dikonversi ke MySQL maupun sebaliknya).

4. Data bangunan ditampilkan di Google Maps. 


\section{FORMULIR PENDATAAN BANGUNAN}

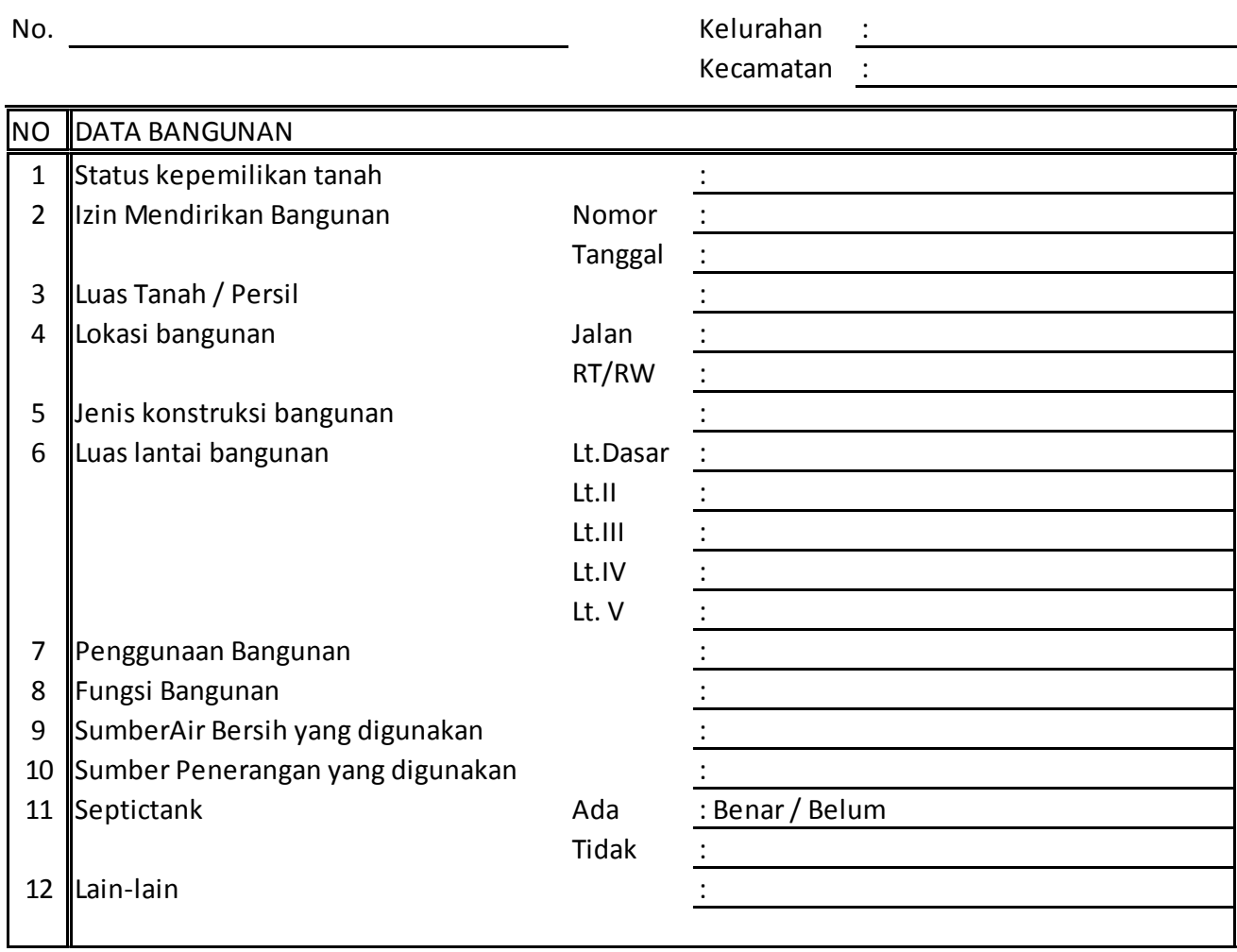

Gambar 2.12 Formulir Isian Pendataan Bangunan

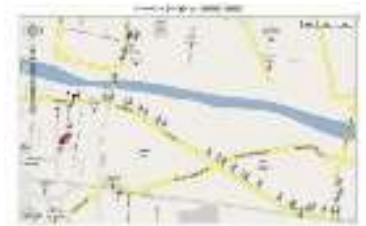

Pemetaan menggunakan GPS

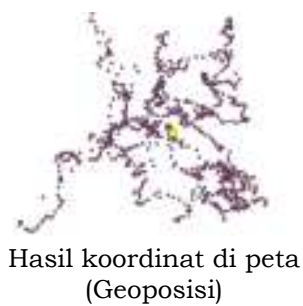

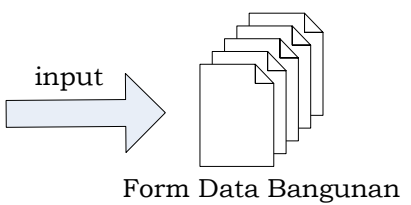

Form Data Bangunan

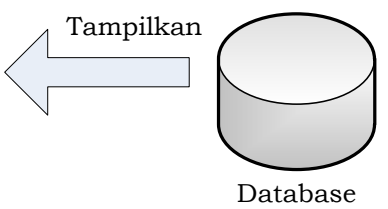

Gambar 2.13 Proses Data Hasil Survey

\section{Daftar Pustaka :}

[1] Undang-undang Nomor 4 Tahun 1992 tentang Perumahan dan Pemukiman.

[2] Undang-undang No.23 Tahun 1997 tenetang Pengelolaan Lingkungan Hidup.

[3] Undang-undang No. 28 Tahun 2002 tentang Bangunan Gedung.

[4] Undang-undang No.26 Tahun 2007 tentang Penataan Ruang.

[5] Undang-undang No.32 Tahun 2009 tentang Perlindungan dan Pengelolaan Lingkungan Hidup. 
[6] Undang-undang No.4 Tahun 2011 tentang Informasi Geopasial.

[7] Peraturan Pemerintah No. 15 Tahun 2010 tentang Penyelenggaraan Penataan Ruang

[8] Peraturan Menteri Pekerjaan Umum Nomor 06/PRT/M/2007 tentang Rencana Pedoman Umum Penyusunan RTBL.

[9] Peraturan Menteri Pekerjaan Umum Nomor 17/PRT/M/2010 tentang Pedoman Teknis Pendataan Bangunan Gedung.

[10] Peraturan Daerah Kota Bukittinggi No. 06 Tahun 2011 tentang Rencana Tata Ruang Wilayah (RTRW) Kota Bukittinggi Tahun 2010-2030

[11] Peraturan Daerah Kota Bukittinggi No. 1 Tahun 2015 tentang Bangunan Gedung Kota Bukittinggi

[12] Peraturan Daerah Kota Bukittinggi Nomor 13 Tahun 2016 tentang Anggaran Pendapatan dan Belanja Daerah Tahun Anggaran 2017;

[13] Peraturan Walikota Bukittinggi Nomor 69 Tahun 2016 tentang Penjabaran Anggaran Pendapatan Belanja Daerah Tahun Anggaran 2017;

[14] Budianto, Eko. 2010. Sistem Informasi Geografis dengan Arc View GIS. Yogyakarta: Andi Offset

[15] Yuliadji RW, Suryono GF, Ruben A. 1994. Aplikasi SIG untuk Pemetaan Informasi Pembangunan. Di dalam Agus W, R Djamaludding,G Hendrarto, editor.Remote Sensing \& Geographic information Systems. Jakarta.

[16] Yousman, Yeyep. 2004. Sistem Informasi Geografis dengan ArcView3.3 Professional. Yogyakarta: Andi Offset 